\title{
Civil Society and Political Participation: What Type of Political Participation is Influenced by Community Level Involvement in Civil Society?
}

\author{
Susanne Wallman Lundisen ${ }^{1,2}$ \\ ${ }^{1}$ Ersta Sköndal University College \\ ${ }^{2}$ Mid Sweden University
}

\begin{abstract}
The aim of this paper is thus to further explore the relationship between involvement in voluntary associations at the community level and specific forms of political participation. We pose the following questions. Do voluntary associations contribute to specific forms of individual political participation in a consociational context? Do voluntary associations encourage forms of political participation aimed at directly interacting with the policy process, or do they promote extraparliamentary forms of protest? The study contributes with testing three different measurements of community level involvement in voluntary associations and their correlations with individual level political participation. The empirical data is based upon a mulitilevel sample of 4232 individuals located in 33 different Swedish municipalities. Results show that only direct contacts with local elites are significantly correlated with community level participation in civil society organizations. This result may be interpreted as indicating that local voluntary associations contribute to the local political culture.
\end{abstract}

Keywords: Civil society, Voluntary associations, Multilevel analysis, Political participation, Political culture

\section{Introduction}

Since de Tocqueville's time, it has been debated whether and how participation in civil society organizations contributes to political participation. The study of Italy by Putnam (1993) argued that a vibrant local civil society produces externalities and influences citizens to become more civically engaged regardless of their level of involvement in civil society. Although several subsequent studies have attempted to empirically test the propositions of Putnam (1993), many aspects of the link between civil society and political participation remain unknown (cf. Schulz and Bailer 2012: 20). The question of whether the context in which one lives is important in determining political participation is both longstanding and disputed (cf. e.g., Huckfeldt et al. 1993: 368-69; Huckfeldt and Sprague 1987).

Voluntary associations within the local context constitute an important part of the social fabric of the daily lives of citizens (Zmerli and Newton 2007). Many citizens tend to be engaged, either as members or as volunteers, in voluntary associations that operate within a local grassroots context; therefore, the role that voluntary associations play in local democracy is important to study (Maloney and Roßteutscher 2007; Roßteutscher 2005). By analyzing individuals' political participation within different local communities in which the presence of voluntary associations and the engagement of citizens in 
voluntary associations vary, this study offers an analysis of whether different forms of political participation, such as individual efforts to influence policy and extraparliamentary activities such as demonstrating, are affected equally.

The aim of this article is thus to further explore the relationship between involvement in voluntary associations at the community level and specific forms of political participation. We pose the following questions. Do voluntary associations contribute to specific forms of individual political participation in a consociational context? Do voluntary associations encourage forms of political participation aimed at directly interacting with the policy process (such as contact with politicians or local civil servants aimed at influencing them), or do they promote extraparliamentary forms of protest (such as participating in demonstrations or signing petitions)? The study contributes with testing three different measurements of community level involvement in voluntary associations and their correlations with individual level political participation.

The paper proceeds as follows: the theoretical concepts that link voluntary associations to political participation are presented, followed by a section that explains how the institutional context matters for the type of political participation and the hypotheses that will be tested. Finally, the data set and the results are presented.

\section{Voluntary Associations and Political Participation}

This section outlines the theoretical arguments concerning the link between voluntary associations at the community level and individual political participation and the following section specifically addresses previous studies that are pertinent to the case of Sweden. Since Almond and Verba (1963) first observed a positive correlation between individual participation in voluntary associations and political participation, this correlation has been empirically corroborated in numerous contexts (Lorenzini and Giugni 2012; Teorell 2003). ${ }^{1}$ The two main causal mechanisms explaining the link between civil society and political participation presented in this section include one that emphasizes individual values and skills (schools of democracy) and a second one that emphasizes the importance of overlapping social networks.

First, it has been argued that voluntary associations function as schools of democracy and demonstrate a capacity to generate broader interest in society among their members and/or volunteers most strongly perhaps in Putnam (1993). Verba et al. (1995) also argued that participation in voluntary associations provides citizens with civic skills (e.g., giving speeches or writing petitions) that facilitate political participation. In essence, this is an individual explanation in which individual participation in voluntary associations may lead to the development of civic skills that, in turn, facilitate different forms of political participation. The civic voluntarism model proposed by Verba et al. (1995) recognizes that political participation has multiple explanations and that different forms of political participation may have different explanations. They recognize that participation in civil society organizations, may be one of the sources that provide individuals with political resources.

\footnotetext{
${ }^{1}$ The debate over whether civil society organizations have positive or negative consequences for democracy and society has been vibrant, and several important contributions have nuanced the initial optimistic picture painted by Putnam (1993) (e.g., Berman 1997; Wollebæk and Selle 2002; Stolle 2001; Van der Meer and van Ingen 2009; Armingeon 2007; cf. Warren 2001; Uslaner 2002). Subsequently, Putnam (2000) also attempted to nuance his interpretation of the normative issue concerning whether civil society organizations have positive or negative consequences for society.
} 
Moreover, other studies have also argued that participation in voluntary organizations may provide members with specific skills regarding how to organize, communicate and address conflicts that are also useful for political participation (Quintelier 2012).

The causal mechanisms underlying these theories generally operate at the individual level, linking individual participation in voluntary associations to learning specific skills useful for political participation.

At the community level, the mechanisms of schools of democracy may create widespread norms of how to behave politically and thus potentially influence others who are not active in civil society organizations; for example, the past successes of local voluntary associations may also influence perceptions of the cooperative spirit of other citizens (Wollebæk and Selle 2007: 4).

Second, participation in civil society organizations seems to be able to provide a social network infrastructure that connects individuals in a local community (Coleman 1990; Freitag et al 2009; Putnam 1993; Teorell 2003; Wollebæk and Stromsnes 2008). When defining what constitutes social capital, both Putnam (1993) and Coleman (1990) include social networks and their capacity to facilitate collective action. Coleman and Putnam ${ }^{2}$ differ from Bourdieu in the sense that they interpret social networks not only as an individual resource but also, more importantly, as a resource of the local community (Putnam 1993: 167).

Huckfeldt and Sprague (1987: 1200) made an important analytical distinction between social networks, which are being deliberately formed by individuals through their choices, and context, which is "structurally imposed" on individuals. Huckfeldt and Sprague (1987: 1201), however, also recognized that in practice, this distinction between context and networks may be blurred. In the case of community-level involvement in civil society organizations, civil society organizations may not only constitute part of the social networks of those who are connected to these organizations but also be part of the community context for those who are not connected to any of these organizations.

Books and Prysby (1988: 223) proposed that the contextual effects on political participation could be regarded as being the result of differences in how information is patterned. Individuals can obtain information from the context in several different ways, such as through participation in voluntary associations. As a means of understanding the contextual effects of community-level participation in civil society organizations the presence of many or few civil society organizations generally structures the information flow that is available to citizens in different ways.

Extensive social networks may, according to Granovetter (1973), facilitate the flow of useful information. Useful information with regard to political participation may include becoming aware of and being requested to politically participate in specific issues (Teorell 2003). However, useful information with respect to attempts to influence decisions on community issues may also include information on where to turn and whom one should contact in order to have an influence on community issues. Through social networks, citizens are also exposed to requests for political participation and to the social norms that are associated with such participation (Mutz 2002; Teorell 2003; Verba et al. 1995).

\footnotetext{
2 Although the definitions used by Coleman (1990) and Putnam (1993) have been heavily criticized for containing circular arguments (notably by Portes 1998), in a systematic literature review, Fulkerson and Thompson (2008) demonstrated that the group- and community-level resources, rather than the individual-level resources interpretation of social capital, represent the most widespread interpretation. This group- and community-level resource interpretation of social capital also echoes the original use of the term by Hanifan (1916).
} 
Lake and Huckfeldt (1998) considered the importance of social networks in the creation of what they termed politically relevant social capital. The authors argued that political engagement is enhanced through interaction with others. Lake and Huckfeldt's results also indicated that the relationship between social networks and political participation depends on the level of political expertise, the frequency of interaction and the size of the social network, and they downplayed the role of individual organizational involvement (Lake and Huckfeldt 1998: 582). Schulz and Bailer (2012) further investigated the importance of the types of political associations in which members are involved. Certain types of political participation were found to be more frequently undertaken by members if the voluntary associations to which they belong are embedded in their local communities and have strong ties to local political elites.

The presence of a large number of civil society organizations such as voluntary associations per capita in a local community increases the likelihood that overlapping social networks will form and that these networks will also constitute part of the social context of the community. The causal mechanisms linking community-level involvement in civil society organizations to individual political participation would then primarily stem from how the different presence of these organizations structures the information that is available to citizens. In a context with a strong presence of voluntary associations, politically relevant information may be more easily accessible to the inhabitants of such a local community.

\section{Placing Voluntary Associations in an Institutional Context}

Given the theoretical frameworks elaborated above, it is logical to assume that a high level of community involvement in voluntary associations may affect political participation at the individual level through contextual effects. However, voluntary associations do not exist in a complete vacuum but rather are influenced by the institutional context in which they operate. To elaborate the main hypotheses regarding whether community level involvement in voluntary associations is likely to affect all types of political participation, we must first outline the context of Sweden in greater detail. To better understand the link between voluntary associations and specific forms of political participation, it is important to place voluntary associations in their political context (cf. Stadelmann-Steffen and Freitag 2011; Schofer and Fourcade-Gourinchas 2001).

Previous studies have shown that the institutional framework influences both the types of voluntary associations that emerge and the manner in which these organizations are civically engaged (Kriesi and Baglioni 2003; Schofer and Fourcade-Gourinchas 2001; StadelmannSteffen and Freitag 2011). By using information on the characteristics of the specific institutional setting, we may also advance hypotheses concerning which forms of political participation may be susceptible to local differences in the presence of voluntary associations.

As Schofer and Fourcade-Gourinchas (2001: 811-3) have noted, institutional constraints affect both the types of involvement that occur in civil society and the civic engagement of these civil society organizations. Sweden is characterized by a low degree of political power centralization (statism) and a high degree of social actor incorporation (corporateness) (Schofer and Fourcade-Gourinchas 2001).

Several political theorists have characterized the Swedish model of governance, similar to the Swiss model, as being focused on consensus. Sweden has been described as a political system that is relatively open to the influence of civil society organizations on the input side (Kitschelt 1986; cf Lijphart 1999). Kitschelt (1986: 64) argued that both the openness of a political system toward groups in society that attempt to influence policy and the capacity of 
a political system to produce policy affect the strategies that groups will employ in their attempts to influence policy. The input openness (or lack thereof) and the political output structures jointly form political opportunity structures.

In the Swedish case, several historical studies have repeatedly confirmed that at least since the late $19^{\text {th }}$ Century and beginning of the $20^{\text {th }}$ Century, local voluntary associations most frequently participated in local politics by attempting to influence public opinion and through contacts with politicians (Back 1967; Lundkvist 1977; Micheletti 1995). More recent studies have revealed a decline in corporatist connections between civil society organizations and politics (Christiansen et al 2010; Lundberg 2012; Öberg et al 2011).

Moreover studies have also argued that engagement in civil society may affect various forms of political participation in different ways (Knoke 1986: 9; Olsen 1982). Civil society organizations contact politicians and mobilize their members often with regard to specific issues (Öberg and Svensson 2012). Approximately 50\% of Swedish voluntary associations contact local politicians at least once per year (Öberg and Svensson 2012; Wallman Lundåsen, 2014a). According to Olsen (1982), activities within voluntary associations are more likely to affect contacting elites than other broader forms of political participation, such as turnout, because most voluntary associations are more likely to mobilize their members with regard only to specific narrow issues rather than through broad campaigns. A recent study by Öberg and Svensson (2012) conducted in Sweden to map the political participation of voluntary associations seems to corroborate these assumptions, as direct contacts with politicians and the media seem to be the preferred channels through which voluntary associations exercise influence. Similar results are also found in more recent studies by Wallman Lundåsen (2014a).

Therefore, the institutionalized cooperation and democratic infrastructure connected to community level involvement in civil society as noted by Wollebæk and Stromsnes (2008) may have a specific meaning in the Swedish context, as also noted by Kitschelt (1986). The political opportunity structures characterized by relative openness on the input side of the political system made it possible and useful for voluntary associations to closely interact with policymakers while making relatively less use of direct confrontations (cf. Wallman Lundåsen, 2014b). The empirical findings by Öberg and Svensson (2012) also suggest that the type of political participation that is likely to be most associated with a strong presence of local voluntary associations is direct contacts with local policymakers. Therefore, the following hypothesis can be formulated:

Hypothesis 1: Communities with a higher density of voluntary associations are likely to encourage individual political participation in the public policy process through, e.g., direct contacts.

Because voluntary associations are argued to institutionalize collective action, we may also assume that certain forms of political participation would be enhanced by the existence of a broad, community-level infrastructure of voluntary associations such as more collective forms of political participation like e.g., participating in demonstrations. Citizens who participate in demonstrations and petitioning may however have different underlying personal motivations than citizens who pursue other forms of political participation. Participating in a demonstration or signing a petition may be satisfying on a personal level and may have "entertainment value", regardless of the outcomes of these actions (cf. Bäck et al. 2011: 78). Therefore, political protests, such as participation in boycotts, demonstrations and petition signing, likely also have individualistic motivations.

Historically, demonstrations, petitioning and other forms of protest activities could also be considered more of a last resort rather than a first choice for a Swedish voluntary 
association attempting to obtain political support for its requests for a change in policy (cf. Lundkvist 1977; Kitschelt 1986). As Kitschelt (1986) also noted, confrontational political protests are less likely to occur in relatively open political systems such as that found in Sweden. Additionally, the mechanisms described by Mutz (2002) in which citizens tend to avoid conflict may be more relevant in a local context with a stronger presence of voluntary associations (cf. Goodin 2010) than in other contexts; therefore, political participation that is more strongly correlated with conflicts such as demonstrations may be more limited in these contexts. It can thus be hypothesized that broad participation in voluntary associations is correlated with norms that encourage non-confrontational political behavior.

Therefore, the following hypothesis can be formulated:

Hypothesis 2: Communities with a higher density of voluntary associations are less likely to have citizens who are involved in extraparliamentary activities (such as petitioning and demonstrating) than communities with fewer voluntary associations.

\section{Data and Methods}

\section{Data}

The current study is based on survey data that were collected from 33 municipalities in Sweden. The use of the "most similar system design" and a comparison of municipalities within Sweden yield considerable advantages (Lijphart 1971; Peters 1998). In this case the national-level context is constant. Additionally, previous studies have shown that membership and levels of engagement in voluntary associations are correlated with differences in how welfare systems are arranged or correlated with other institutional constraints (cf. Schofer and Fourcade-Gourinchas 2001; Salamon and Anheier 1998). We can also draw conclusions from previous studies that have shown that the same types of associations may have different meanings and societal roles in different countries (Stolle 2001). It is therefore appropriate to perform a within-country comparison to keep the institutional setting constant.

The survey was distributed by mail, and the data collection occurred from June 2009 to November 2009. A two-step sampling method was used to select the municipalities and it was designed to increase variation (within the relatively homogenous country) in the contextual variables among the sampled municipalities. First, all of the Swedish municipalities (290) were classified as high or low with respect to the following four variables: immigrationrelated diversity (measured as: the proportion of the population born in a non-Nordic country), socioeconomic inequality (measured as: the number of unemployed people in combination with the proportion of citizens who receive social welfare), church attendance (measured as: attendance in mass from official statistical records kept by the Church of Sweden) and crime rates (measured as: the proportion of reported crime per capita). A matrix containing the different combinations (high and low for the four contextual variables) was constructed, and the 290 municipalities were placed in 16 subgroups. The 16 different subgroups represented municipalities with different degrees of these four variables in order to have a more distribution of the different variables instead of for instance ending up with only municipalities with extreme levels of the selection variables. Two municipalities were randomly drawn by Statistics Sweden from each subgroup. One municipality (Malmö) was added after the sample had been drawn to include one of the three major urban areas in Sweden. Thereafter a random sample of 400 residents aged 18 to 85 was drawn from the all of the 33 municipalities. The sample of individuals was drawn from the total population 
register (RTB) maintained by Statistics Sweden. Each respondent within the sample is connected to his or her municipality of residence, which corresponds to the lowest administrative level in Sweden. The municipalities that were surveyed differed in population size. During the study period, the mean population size in the municipalities was 33,058 inhabitants; the largest municipality in the sample had 286,000 inhabitants, and the smallest municipality had 2,700 inhabitants.

The overall response rate was $51.2 \%$, and the total number of respondents was 6,453 . The actual number of respondents used in the analyses was lower because of internal no response (either system missing or don't know). At the municipality (aggregate) level, we relied on official statistical data provided by Statistics Sweden. These data include both demographic statistics (such as population size and the educational levels of municipal residents) and information pertaining to the number of active voluntary associations in the municipalities. To analyze the data hierarchical linear analyses were performed using HLM 2.

\section{Dependent Variables}

The dependent variables for political participation were constructed through principal component analysis using five different survey items on political participation. These survey items included questions on the respondent having contacted officials within the local public administration and local politicians to influence them on a community issue, as well as items regarding having signed petitions, participated in legal demonstrations and participated in boycotts during the past 12 months (see Table 1 further ahead in the text for the result of the factor analysis).

\section{Independent Variables}

The following measures of community-level involvement in voluntary associations were used. The density of voluntary associations was calculated as the number of voluntary associations divided by the population and multiplied by 1,000. To minimize heteroskedasticity, the density figure was logarithmically transformed.

Two additional measures of engagement in voluntary organizations that were aggregated from the survey data were also introduced. Registration as a voluntary association is voluntary if the voluntary association is economically inactive, which creates uncertainty regarding the extent to which the official statistical records on the number of voluntary associations actually reflect differences in activity within the local civil society organizations. The two additional measures of community-level involvement in voluntary associations are: the proportion of individuals in the population who are members of at least one voluntary association and the average number of distinct voluntary associations for which respondents in the municipality volunteer (labeled as aggregated volunteer index), aggregated from the survey data.

The aggregate (municipal) correlation between associational density and the proportion of individuals in the population who are members of at least one voluntary organization is $0.55(\mathrm{p}<0.001)$, and the correlation between associational density and average number of distinct voluntary associations for which respondents in the municipality volunteer (aggregated volunteer index) is $0.64(\mathrm{p}<0.001)$. This result shows that volunteering with several organizations is strongly correlated with the density of voluntary associations, implying that citizens in communities with a large number of organizations are also likely to participate in multiple associations. 
At the individual level, active involvement in associations through both volunteering and membership are controlled (cf. Selle and Strømnsnes 2001). Refer to the appendix for descriptive statistics pertaining to the central individual- and community-level variables. Although it is impossible to control for all of the possible correlations to eliminate spurious correlations, it is possible to introduce theoretically known variables that are intended to eliminate or weaken the correlation of the variables associated with involvement in voluntary associations and the community-level density of voluntary associations.

Several other contextual-level explanations for political participation have been advanced in previous studies, and these variables are introduced here as control variables. These variables include community size and population density, which are believed to influence political participation (Carr 2008; Oliver 2001). Ethnic diversity has also been offered as a community-level explanation of individual-level participation (Tolsma et al. 2009). The level of education (the proportion of the population with low levels of education) and economic inequality (the Gini coefficient) within a community are also controlled for in this study.

At the individual level, we control for socioeconomic and demographic characteristics, such as age, gender, education (low to high) (Armingeon 2007; Gesthuizen and Scheepers 2012), and variables related to political interest and political efficacy (the belief in one's capacity to influence policy) (van Deth 1996).

\section{Results}

First, an exploratory principal component analysis was conducted to investigate the different dimensions of political participation within the dataset. The analysis reveals two main factors of participation among the items in the survey: contact and protest (see the appendix for the question wording). This result is consistent with previous findings, although the wording of the question items is not identical (Armingeon 2007; Bäck et al. 2011; Schulz and Bailer 2012). These two dimensions employed separate participation indices using the factor scores as dependent variables; the two dimensions are labeled as contact and protest (see Table 1). The primary reason for the use of factor scores rather than a multinomial analysis is that this study focuses on distinguishing among different dimensions of participation rather than different survey items related to political participation.

By aggregating the factor scores of the two dimensions of political participation at the municipal level, we can measure the aggregate correlation between contacts and protests and the density of voluntary associations in the municipalities. Table 2 displays the aggregatelevel correlations between contacts and protests and the density of voluntary associations.

Table 1: Exploratory Principal Component Analysis of Political Participation Items

\begin{tabular}{lcc}
\hline & Contact & Protest \\
\hline Contact: a politician to influence a decision on a community issue & 0.895 & 0.117 \\
Contact: a civil servant to influence a decision on a community issue & 0.892 & 0.118 \\
Participate: peaceful demonstration & 0.182 & 0.771 \\
Participate: boycott & 0.098 & 0.674 \\
Participate: petition (also on the internet) & 0.008 & 0.565 \\
\hline
\end{tabular}

Note: Principal component analysis, varimax rotation with Kaiser normalization. The factors explain $60.9 \%$ of the variation. $\mathrm{N}=4232$ 
Table 2: Aggregate-Level Involvement in Voluntary Associations and Political Participation; Aggregate-Level Bivariate correlations, Pearson's r

\begin{tabular}{lccc}
\hline & $\begin{array}{c}\text { Density of voluntary } \\
\text { associations }\end{array}$ & $\begin{array}{c}\text { Member of at } \\
\text { least one voluntary association }\end{array}$ & Volunteer index \\
\hline Contact & $0.71^{* * *}$ & $0.68^{* * *}$ & $0.64^{* * *}$ \\
Protest & $-0.30^{*}$ & -0.24 & -0.25 \\
\hline
\end{tabular}

Note: $* * * p<0.0001 ; * p<0.05, \mathrm{~N}=33$.

The aggregate-level correlation between the contact dimension and the density of voluntary associations is strong at 0.71 (statistically significant, $\mathrm{p}<0.001$ ). By contrast, the aggregate-level correlation between protests and the density of voluntary associations is weaker $(-0.3)$, and the coefficient is negative (statistically significant, $\mathrm{p}<0.05$ ). The correlations for the other two variables that measure community level involvement in civil society are similar in size and also significant for the contact dimension. Table 2 also indicates that the correlations with the protest dimension is not significant for the other two variables (share of population that is member in at least one voluntary association and the volunteer index). However, we must acknowledge that the bivariate correlation at the aggregate level may be influenced by other variables, such as population size (smaller municipalities tend to have a greater number of voluntary associations per capita and higher levels of personal contacts between politicians/administrators and citizens).

Therefore, we proceeded to the multilevel modeling and created different models to test the influence exerted by the density of voluntary associations on the two forms of political participation.

The empty models reveal that the municipal-level variance components are statistically significant for both of the dependent variables. Therefore, multilevel analysis was deemed appropriate. For the contact variable, the intraclass correlation coefficient (ICC) is 0.11 ; thus, $11 \%$ of the variance is explained by community-level factors. For protests, the intraclass correlation equals 0.08 and is also statistically significant.

A model that contains all of the control variables and the density of voluntary associations at the community level was constructed (Model I, contact/protests see Table 3). For the contact dimension of political participation, the density of voluntary associations is a significant explanatory variable. The associational density variable should according to the hypothesis 1 be positively correlated with contacts and as predicted by hypothesis 1 the coefficient is positive and significant $(\mathrm{p}<0.01)$, even after including the control variables at both the individual and aggregate levels.

The difference in the predicted contact variable scores between those who live in the municipality with the lowest density of voluntary associations per capita and those who live in the municipality with the highest density of voluntary associations within the sample of municipalities corresponds to 0.25 standard deviations. All else being equal, an individual who lives in a municipality with many voluntary associations per capita is slightly more likely to attempt to influence the policy process through contact with civil servants or politicians regarding a local community issue compared with a citizen whose municipality has fewer voluntary associations per capita.

Knowledge of where to turn to influence a community issue is positively correlated with contacts $(\mathrm{p}<0.000)$ as logic also would assume. At the aggregate level, there is a significant correlation $(0.30, \mathrm{p}<0.05)$ between the density of voluntary associations and knowing whom to contact. The aggregate-level correlation between the proportion of 


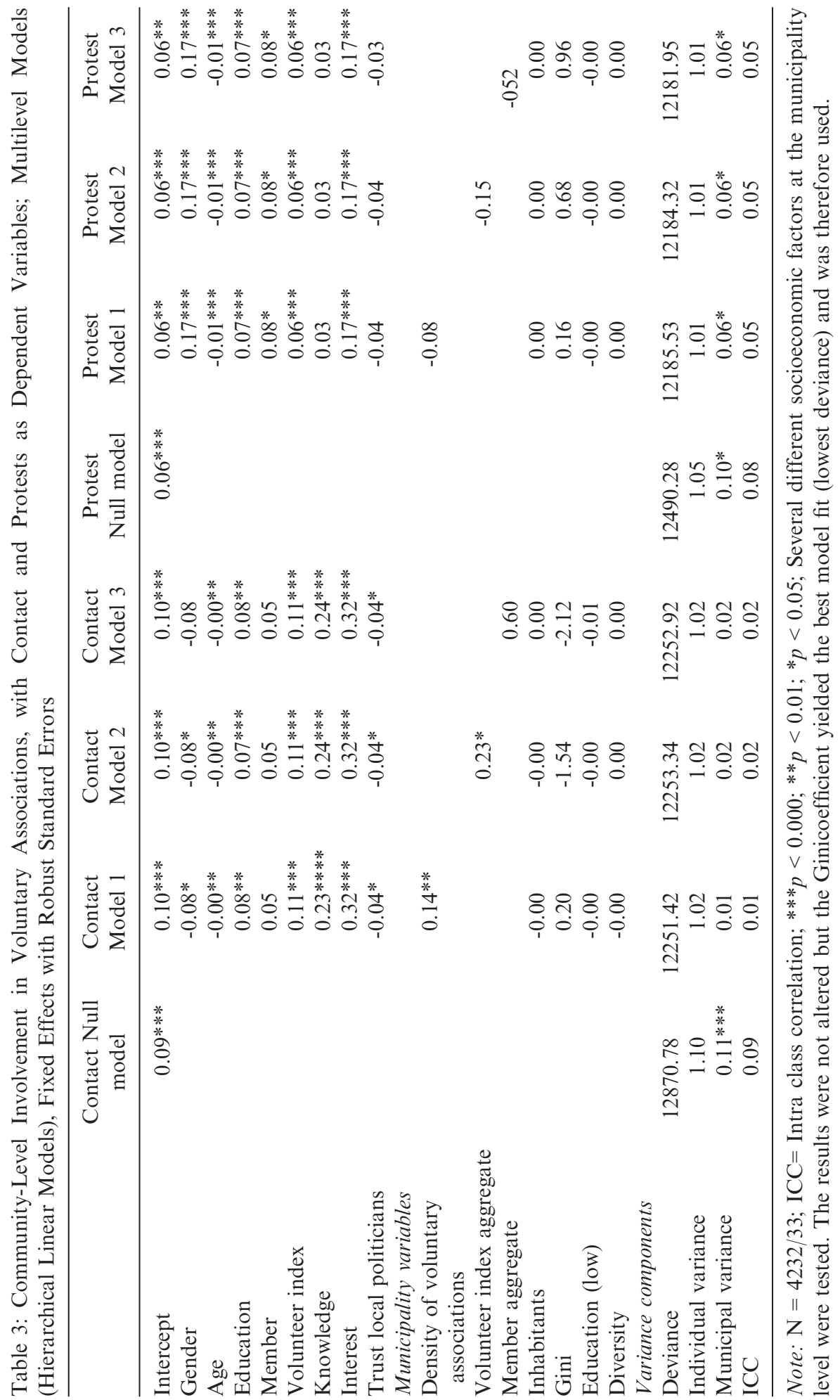


individuals in the population who have volunteered in different voluntary associations and knowing whom to contact is even stronger $(0.60, \mathrm{p}<0.000)$.

A potentially counterintuitive finding is that individuals with lower levels of trust in their local politicians also tend to contact their civil servants and local politicians more frequently to influence them with regard to community issues. However, individuals with high levels of trust in their local politicians may not even consider contacting them, as they trust them to make the correct political decisions even without the influence of citizens. Lower levels of trust may indicate healthy skepticism regarding local leaders. It is also possible that citizens in local communities with numerous voluntary associations may feel the need to contact their local elites more frequently, as there is stronger competition among the multitude of voluntary associations over limited and scarce local resources. Moreover, previous studies have shown a negative correlation between density of voluntary associations and trust in local political institutions (Aars and Christensen 2013).

To control for bias in the associational density figure in the register data, we introduce two measurements from the survey to analyze aggregate-level engagement. We introduce these variables in different models, given their high correlation and the multicollinearity problems that this high degree of correlation may cause. The first of these variables is a measurement of the average proportion of citizens who are reported to be actively involved in at least one voluntary organization. The second variable refers to the number of different types of organizations in which these citizens are involved (the breadth of involvement) (Table 3). Table 3 shows that the average number of different types of voluntary organizations in which citizens volunteer has a statistically significant and positive effect on individual-level contacts. When the average level of involvement in different types of voluntary associations at the community level increases, the likelihood that residents in these communities will use contact as a form of political participation also increases, consistent with the first hypothesis. The coefficient indicates that if citizens at the municipal level increase their average active involvement by one (that is, become actively involved in one additional type of voluntary association), political participation through personal contacts increase by 0.23 standard deviations, all else being equal.

By using data from the actual municipalities, an estimate of the expected values (when holding all other variables constant at their mean values) shows that the difference in contacts between those who live in the community with the greatest involvement in voluntary associations and those who live in the community with the least involvement in the sample of municipalities corresponds to 0.22 standard deviations. This result is similar to the predicted effect of the associational density variable.

Table 3 also shows that the average proportion of citizens within the municipality who are members in at least one voluntary associations has a positive coefficient; thus, an increase in the proportion of community-level participation in voluntary associations would increase the level of individual-level contacts. However, this correlation was not found to be statistically significant at conventional levels.

Moreover, Table 3 shows that none of the measurements of community level involvement in civil society are significantly correlated with the protest dimension of political participation. The lack of significant correlations with protests is consistent, regardless of the type of aggregate-level measurement of associational involvement that is used. At the individual level the other control variables for political knowledge and political trust are also insignificant. Whereas the effect of political interest still is significant although the coefficient is markedly lower than for the contact dimension. 
The lack of a significant correlation between aggregate-level involvement in voluntary associations and individual political participation through the protest dimension does not confirm the second hypothesis. In summary, the only dimension of political participation that is affected by community-level involvement in civil society is direct contact with local elites.

\section{Conclusion}

In contrast with many previous studies, the current study used a multilevel approach that enables an estimation of correlations of involvement in voluntary associations at both the community and individual levels. Further contrasting with previous studies, the current study used three different measures of community-level associational involvement: organizational infrastructure (the density of voluntary associations), the breadth of involvement in voluntary associations (different types of organizations for which citizens volunteer) and the proportion of the population that is a member of at least one voluntary association.

The aim was to investigate whether the aggregate involvement in voluntary associations had an influence on specific forms of individual political participation. This study has focused on examining how the presence of a multitude of voluntary associations at the local level affects the type of political participation in which citizens are most likely to be engaged. Given the institutionalized relationship between voluntary associations and the state in Sweden, the expectation was that forms of political participation based on direct contacts were more likely. The study has also shown that there are local variations within Sweden with respect to patterns of political participation and that the breadth of involvement in voluntary associations plays a role in explaining these differences (cf. Wollebæk and Stromsnes 2008).

A strong local presence of a multitude of voluntary associations is likely to have influenced the local political culture in a direction that favors direct contacts between citizens and local leadership, given the specific institutional context of Sweden. The institutionalized democratic infrastructure composed of voluntary associations has likely strengthened a specific type of political participation through direct contacts, as this type of political participation is privileged by voluntary associations. A large number of voluntary associations per capita may be a related to the political opportunity structures (Kitschelt 1986) and may thus explain the lack of correlation between protest-oriented forms of political participation and community-level involvement. The voluntary associations themselves may institutionalize specific forms of local political participation that also have an influence on the political behavior of the residents of the local community.

We suggest three possible interpretations of these findings. The conclusions must be interpreted with caution, as the study only investigated certain forms of political participation. However, voluntary associations are more likely to use direct contacts themselves as a means of influencing politics, and therefore, individuals living in contexts with numerous voluntary associations may be more likely to prefer direct contacts as a means of political participation (cf. Öberg and Svensson 2012). These findings lend support to the notion that voluntary associations are more likely to mobilize their members for direct contact with politicians than to provide general incentives for broader forms of participation (cf. Olsen 1982; Bäck et al. 2011). This result may be interpreted as indicating that local voluntary associations contribute to the formation of the local political culture, with their presence influencing how the inhabitants in these local 
communities engage in political participation. The result confirms that the institutional setting has an influence on the type of political participation that is observed in communities with a large number of voluntary associations (cf. Freitag 2006; StadelmannSteffen and Freitag 2011; Wallman Lundåsen, 2014a).

Second, the stronger presence of overlapping social networks that exist in communities that have many voluntary associations may influence the knowledge of whom to contact, and the possible transitivity in these networks (A knows B, who knows $\mathrm{C}$, and $\mathrm{C}$ knows whom to contact) may also increase the opportunities for contact. The results also showed that knowledge on whom to contact is also positively correlated with contacting. Knowledge on where to turn was also found to be positively correlated at the aggregate level with the presence of and activity within voluntary associations. This result may indicate that voluntary associations contribute to structuring the information that is available to citizens, as suggested by Books and Prysby (1988). However, there is an additive effect from living in a context with numerous voluntary associations, meaning that personal knowledge on where to turn, coupled with a density of voluntary associations, increases the likelihood that an individual will contact local elites. These findings are in line with previous studies that stress the importance of the number of affiliations with voluntary associations rather than the type of activity these associations are involved with for political participation (cf. Teorell 2003; Freitag et al 2009). Further the results are in line with the causal mechanisms advanced by social network theories (cf. Teorell 2003).

Third, contact with politicians may be considered a more efficient means of influencing policy than demonstrations and petitions. The past legacy of a close relationship between the state and civil society may have been stronger in communities with a large number of voluntary associations and therefore may have shaped the local political culture more noticeably than in communities with fewer voluntary associations. Local political norms may have been shaped to avoid direct conflicts through political actions such as demonstrations (cf. Mutz 2002; Kitschelt 1986). The variables that measure communitylevel involvement in voluntary associations cannot explain the variation in the protest variable. The lack of correlation between the local strength of voluntary associations and these more protest-oriented forms of political participation may indicate that these forms are considered last resorts rather than preferred options for political participation in communities with a large number of voluntary associations.

However, these findings also raise important questions regarding the link between vibrant civil society at the local level and political participation. If the correlation exists only for contact form of political participation, then the implication is that personal ties between local elites and local civil society organizations may facilitate influence through direct contacts. These results should not be interpreted only in view of the non-existent correlation with the other form of political participation. Overlapping social networks and personal ties that are used to exercise political influence may be problematic in different ways; they give certain citizens an advantage in terms of influencing policy based on personal ties. Additionally, because such contacts may be made outside of the public spotlight, local elites are less likely to be held accountable for the results of these contacts. Moreover, in line with Öberg and Svensson (2012), direct contacts may, in the long run, lead to an impoverished public debate, as arguments are not presented to the general public but rather only to a restricted group (cf. Wallman Lundåsen, 2014a). Whether and to what extent groups of citizens should influence policy between elections is a normative question, and these results show that the local elites in certain communities are approached by citizens more often than the local elites in other communities. 


\section{Acknowledgement}

I would like to express my gratitude to the anonymous reviewers and the editors for comments on previous versions of the text. The study was supported by grants from Riksbankens Jubileumsfond and Vetenskapsrådet.

\section{References}

Aars, J. and D.A. Christensen (2013). The Impact of Local Associational Life on Citizens' Attitudes towards Local Government. Policy \& Politics 41(3): 371-87.

Almond, G.V.S. (1963). The Civic Culture: Political Attitudes and Democracy in Five Nations. Boston: Little, Brown.

Armingeon, K. (2007). Political Participation and Associational Involvement. In van Deth, J., R. T. Montero and A Westholm (eds.), Citizenship and Involvement in European Democracies: A Comparative Analysis. London: Routledge/ECPR.

Bäck, H., J. Teorell and A. Westholm (2011). Explaining Modes of Participation: A Dynamic Test of Alternative Rational Choice Models. Scandinavian Political Studies 34(1): 74-97.

Back, P. E. (1967). Sammanslutningarnas Roll I Politiken 1870-1910. Lund: Studentlitteratur.

Berman, S. (1997). Civil society and the collapse of the Weimar Republic. World politics 49(03): 401-429.

Books, J. and C. Prysby (1988). Studying Contextual Effects in Political Behavior: A Research Inventory and Agenda. American Politics Research 16(2): 211-38.

Carr, J. (2008). City Size, Density, and Political Participation in Local Government, Paper Presented at the Annual Meeting of the Midwest Political Science Association, April, 3-6, 2008: Chicago.

Christiansen, P. M., A. S. Nørgaard, H. Rommetvedt, T. Svensson, G. Thesen and P. O. Öberg (2010). Varieties of Democracy: Interest Groups and Corporatist Committees in Scandinavian Policy Making. Voluntas 21(1): 22-40.

Coleman, J. (1990). The Foundations of Social Theory. Cambridge: Harvard University Press.

Erlach, v. E (2005). Politisierung in Vereinen. Eine Empirische Studie zum Zusammenhang Zwischen der Vereinsmitgliedschaft und der Teilnahme Anpolitischen Diskussionen. Swiss Political Science Review 11(3): 27-59.

Freitag, M. (2006). Bowling the State Back In: Political Institutions and the Creation of Social Capital. European Journal of Political Research 45(1): 123-52.

Freitag, M., N. Grießhaber and R. Traunmüller (2009). Vereine als Schulen des Vertrauens?: eine Empirische Analyse zur Zivilgesellschaft in der Schweiz. Swiss Political Science Review 15(3): 495-527.

Fulkerson, G.M. and G.H. Thompson (2008). The Evolution of a Contested Concept: A Meta-Analysis of Social Capital Definitions and Trends (1988-2006). Sociological Inquiry 78(4): 536-557.

Gesthuizen, M. and P. Scheepers (2012). Educational differences in volunteering in cross-national perspective: Individual and contextual explanations. Nonprofit and Voluntary Sector Quarterly 41 (1): $58-81$.

Goodin, R. (2010). Reflective Democracy. Oxford: Oxford University Press. [Reprint].

Granovetter, M.S. (1973). The Strength of Weak Ties. American Journal of Sociology 78(6): 1360-80.

Hanifan, L.J. (1916). The Rural School Community Center. Annals of the American Academy of Political and Social Science 67(1): 130-8.

Huckfeldt, R., E. Plutzer and J. Sprague (1993). Alternative Contexts of Political Behavior: Churches, Neighborhoods, and Individuals. Journal of Politics 55(2): 365-81.

Huckfeldt, R. and J. Sprague (1987). Networks in Context: The Social Flow of Political Information. American Political Science Review 81(4): 1197-216. 
Kitschelt, H.P. (1986). Political opportunity structures and political protest: Anti-nuclear movements in four democracies. British journal of political science 16(01): 57-85.

Knoke, D. (1986). Associations and Interest Groups. Annual Review of Sociology 12(1): 1-21.

Kriesi, H.P. and S. Baglioni (2003). Putting Local Associations into Their Context. Preliminary Results from a Swiss Study. Swiss Political Science Review 9(3): 1-34.

Lake, R.L.D. and R. Huckfeldt (1998). Social Capital, Social Networks, and Political Participation. Political Psychology 19(3): 567-84.

Lijphart, A. (1971). Comparative Politics and the Comparative Method. American Political Science Review 65(3): 682-93.

— (1999). Patterns of democracy: Government forms and performance in thirty-six democracies. New Haven: Yale University Press.

Lorenzini, J. and M. Giugni (2012). Employment Status, Social Capital, and Political Participation: A Comparison of Unemployed and Employed Youth in Geneva. Swiss Political Science Review 18(3): 332-51.

Lundberg, E. (2012). Changing Balance: The Participation and Role of Voluntary Organisations in the Swedish Policy Process. Scandinavian Political Studies 35(4): 347-71.

Lundkvist, S. (1977). Folkrörelserna i det Svenska Samhället 1850-1920. Stockholm: Sober.

Maloney, W. and S. Roßteutscher (eds.) (2007). Social Capital and Associations in European Democracies: A Comparative Analysis. London/NY: Routledge.

Micheletti, M. (1995). Civil Society and State Relations in Sweden. Avebury: Adlershot.

Mutz, D.C. (2002). The Consequences of Cross-Cutting Networks for Political Participation. American Journal of Political Science 46(4): 838-55.

Öberg, P.O., T. Svensson, P.M. Christiansen, A.S. Nørgaard, H. Rommetvedt and G. Thesen (2011). Disrupted Exchange and Declining Corporatism: Government Authority and Interest Group Capability in Scandinavia. Government and Opposition 46(3): 365-91.

Öberg, P.O. and T. Svensson (2012). Civil Society and Deliberative Democracy: Have Voluntary Organisations Faded from National Public Politics? Scandinavian Political Studies 35(3): 246-71.

Oliver, J.E. (2001). Democracy in Suburbia. Princeton, NJ: Princeton University Press.

Olsen, M.E. (1982). Participatory pluralism: Political participation and influence in the United States and Sweden. Chicago: Nelson-Hall.

Peters, G.B. (1998). Comparative Politics: Theory and Methods. New York: New York University Press. Portes, A. (1998). The Two Meanings of Social Capital. Sociological Forum 15(1): 1-12.

Putnam, R.D. (1993). Making Democracy Work. Princeton: Princeton University Press.

- (2000). Bowling Alone. New York: Simon \& Schuster.

Quintelier, E. (2012). Socialization or Self-Selection? Membership in Deliberative Associations and Political Attitudes. Nonprofit and Voluntary Sector Quarterly 46(3): 365-91.

Roßteutscher, S. (2005). Democracy and the Role of Associations: Political, Organizational and Social Contexts. London/New York: Routledge.

Salamon, L. and H. Anheier (1998). Social Origins of Civil Society: Explaining the Nonprofit Sector Cross-Nationally. Voluntas 9(3): 213-48.

Schofer, E. and M. Fourcade-Gourinchas (2001). The Structural Contexts of Civic Engagement: Voluntary Association Membership in Comparative Perspective. American Sociological Review 66 (6): 806-28.

Schulz, T. and S. Bailer (2012). The Impact of Organisational Attributes on Political Participation: Results of a Multi-Level Survey from Switzerland. Swiss Political Science Review 18(1): 1-27.

Selle, P., \& Strømsnes, K. (2001). Membership and democracy: Should we take passive support seriously. In Dekker, P and E. Uslaner (eds.) Social capital and politics in everyday life. London: Routledge. 
Stadelmann-Steffen, I. and M. Freitag (2011). Making Civil Society Work: Models of Democracy and Their Impact on Civic Engagement. Nonprofit and Voluntary Sector Quarterly 40(3): 526-51.

Stolle, D. (2001). "Getting to Trust": An Analysis of the Importance of Institutions, Families, Personal Experiences and Group Membership. In Dekker, P. and E. Uslaner (eds.), Social Capital and Participation in Everyday Life. London and New York: Routledge/ECPR.

Teorell, J. (2003). Linking Social Capital to Political Participation: Voluntary Associations and Networks of Recruitment. Scandinavian Political Studies 26(1): 49-66.

Tolsma, J., T. van der Meer and M. Gesthuizen (2009). The Impact of Neighbourhood and Municipality Characteristics on Social Cohesion in the Netherlands. Acta Politica 44(3): 286-313.

Uslaner, E. (2002). The Moral Foundations of Trust. Cambridge: Cambridge University Press.

Van der Meer, T.W.G. and E.J. van Ingen (2009). Schools of Democracy? Disentangling the Relationship between Civic Participation and Political Action in 17 European Countries. European Journal of Political Research 48(2): 281-308.

Van Deth, J.W. (1996). Voluntary associations and political participation. In Gabriel, O.W. and J.W. Falter (eds.), Wahlen und Politische Einstellungen in Westlichen Demokratien. Frankfurt am Main: Peter Lang (389-411).

Verba, S., K.L. Schlozman and H. Brady (1995). Voice and Equality: Civic Voluntarism in American Politics. Cambridge: Harvard University Press.

Wallman Lundåsen, S (2014a). Voluntary Associations within the Local Political Context: How Characteristics of the Organizations and the Local Governments Influence Perceptions of Success. VOLUNTAS - International Journal of Voluntary and Nonprofit Organizations, vol. 25: 4, ss. $1041-1061$.

- (2014b). Democratic Values and Civic Engagement of Local Voluntary Associations. Nonprofit Management \& Leadership, vol. 24: 3, ss. 263-283.

Warren, M. (2001). Association and Democracy. Princeton: Princeton University Press.

Wohlgemuth, D. (2006). Den Responsiva Demokratin?: Effekter av Medborgarnas Delaktighet I Den Lokala Demokratin. Dissertation. Uppsala: Acta Universitatis Upsaliensis.

Wollebæk, D. and K. Stromsnes (2008). Voluntary Associations, Trust, and Civic Engagement: A Multilevel Approach. Nonprofit and Voluntary Sector Quarterly 37(2): 249-63.

Wollebæk, D. and P. Selle (2002). Does Participation in Voluntary Associations Contribute to Social Capital? the Impact of Intensity, Scope, and Type. Nonprofi and Voluntary Sector Quaterly 31(1): $32-61$.

- (2007). Origins of Social Capital: Socialization and Institutionalization Approaches Compared. Journal of Civil Society 3(1): 1-24.

Zmerli, S. and K. Newton (2007). Networking Among Voluntary Associations: Segmented or Integrated? In Maloney, W. and S. Roßteutscher (eds.), Social Capital and Associations in European Democracies: A Comparative Analysis. London/New York: Routledge.

\section{Appendix}

Table 4: Descriptive Statistics of Variables

\begin{tabular}{llll}
\hline Individual Variable & Mean & $\begin{array}{c}\text { Standard } \\
\text { Deviation }\end{array}$ & Range \\
\hline Have contacted public official $(0=\mathrm{No} ; 1=$ Yes $)$ & 0.13 & 0.34 & $0-1$ \\
Have contacted politician $(0=\mathrm{No} ; 1=\mathrm{Yes})$ & 0.11 & 0.32 & $0-1$ \\
Have part. in boycott $(0=\mathrm{No} 1=\mathrm{Yes})$ & 0.06 & 0.24 & $0-1$ \\
\hline
\end{tabular}


Table 4: Continued

\begin{tabular}{llll}
\hline Individual Variable & & $\begin{array}{l}\text { Standard } \\
\text { Deviation }\end{array}$ & Range \\
\hline Have part. in peaceful demonstration $(0=$ No; $1=$ Yes) & 0.04 & 0.19 & $0-1$ \\
Have signed petition $(0=\mathrm{No} ; 1=$ Yes) & 0.30 & 0.66 & $0-1$ \\
Member $(0=$ No; $1=$ Yes) & 0.66 & 0.44 & $0-1$ \\
Index volunteering (number of different voluntary & 1.21 & 1.52 & $0-16^{*}$ \\
$\quad$ associations have volunteered for) & & & \\
Trust in local politicians & 1.94 & 0.96 & $1-5$ \\
Knowledge & 2.01 & 0.76 & $1-3$ \\
Interest & 3.44 & 0.99 & $1-5$ \\
Education (1 = compulsory; 2 & 1.94 & 0.77 & $1-3$ \\
$\quad$ secondary; 3 university) & & & \\
Municipality variables & & & $0.21-19.33$ \\
Associations/1000 inhabitants (log) & 5.0 & 4.36 & $0.85-1.68$ \\
Have volunteered for number of & 1.18 & 0.18 & \\
$\quad$ different organizations (mean) & & & $0.49-0.74$ \\
Member of at least one organization (mean) & 0.62 & 0.05 & $2733-286500$ \\
Inhabitants & 33058 & 52622 & $8.1-23.3$ \\
Population with lowest level education (percent) & 17.09 & 3.67 & $1.30-19.40$ \\
Diversity (percent born outside the Nordic countries) & 5.52 & 4.01 & $0.27-0.41$ \\
Gini & 0.33 & 0.03 & \\
\hline
\end{tabular}

*= Filtering out the extreme maximum values of volunteering did not alter the result.

Table 5: Survey Items Question Wording and Coding of Central Individual Level Variables

\begin{tabular}{ll}
\hline Question & \multicolumn{1}{c}{ Coding } \\
\hline $\begin{array}{l}\text { Are you a member of any of the following associations? } \\
\text { Have you volunteered for any of the following }\end{array}$ & Yes $=1$, No $=0$ \\
organizations during the past 12 months? & \\
(list of different types of organizations): & \\
Sports and recreation & \\
Housing, tenant, homeowner & \\
Local interest group & \\
Religious congregation & \\
Culture & \\
Trade union & \\
Parents' association & \\
Senior citizens' association & \\
Immigrants' association & \\
Disability or diagnosis association & \\
Local history association & \\
Charity & \\
Hobby organization & \\
Consumers' co-operative \\
Motor organization \\
Other association
\end{tabular}


Table 5: Continued

\begin{tabular}{ll}
\hline Question & \multicolumn{1}{c}{ Coding } \\
\hline Interest: How interested are you in local social issues? & $1=$ Not interested at all; \\
& $2=$ Quite uninterested; \\
$3=$ Quite interested; & $4=$ Very interested \\
& No=1, Sometimes=2; Almost always=3 \\
Knowledge: Do you have the knowledge where to turn & 5 point Likert scale; $1=$ Very little or \\
to influence local social issues? & none $-5=$ A lot \\
Political trust: Do have trust in the governing local & 5 point Likert scale; $1=$ Very little \\
political parties in your municipality? & responsibility- $5=$ A very great \\
Responsibility: Do you feel responsibility for & responsibility \\
your local community? &
\end{tabular}

Susanne Wallman Lundåsen is a Researcher at the Institute for Civil Society Studies at Ersta Sköndal University College, Stockholm, Sweden and Associate Professor of Political Science at Mid Sweden University, Sundsvall, Sweden. Address for correspondence: Institute for Civil Society Studies, Ersta Sköndal University College, PO Box 11189, 10061 Stockholm, Sweden. Phone: +46771975000; Email: susanne.wallman-lundasen@miun.se. 